\title{
Conversational Style and Early Academic Language Skills in CLIL and Non-CLIL Settings: A Multilingual Sociopragmatic Perspective
}

\author{
Richard Nightingale ${ }^{1} \&$ Pilar Safont ${ }^{1}$ \\ ${ }^{1}$ LAELA Research Group, Faculty of Humanities and Social Sciences, Universitat Jaume I, Castelló, Spain. \\ Correspondence: Richard Nightingale, Departament d'Estudis Anglesos, Facultat de Ciències Humanes i Socials, \\ Universitat Jaume I, Av. Sos Baynat, s/n, 12071 Castelló de la Plana (Spain).
}

Received: October 4, 2018 Accepted: January 5, 2019 Online Published: January 8, 2019

doi: 10.5539/elt.v12n2p37 URL: https://doi.org/10.5539/elt.v12n2p37

\begin{abstract}
As academic language skills develop, young learners are able to rise to the challenge of increasingly complex communication in increasingly formal settings (Snow, 2014; Uccelli et al., 2015). Studies suggest that CLIL contexts may favour the development of academic language skills (Dalton-Puffer, 2007; Nikula, 2007; Marsh, 2008; Pasqual Peña, 2010) to a greater extent than non-CLIL contexts. However, research that attempts to test this assumption has so far tended to do so from a pragmalinguistic perspective (Lorenzo \& Rodríguez, 2014; Lorenzo, 2017). This paper takes a sociopragmatic approach to exploring the differences between CLIL and non-CLIL contexts regarding how they facilitate the development of early academic language skills. That is, how the communicative intentions that underlie CLIL and non-CLIL classroom discourse may help or hinder the development of such skills. The data were collected by observing classroom discourse in CLIL and EFL primary-school lessons, in Spanish-based and Catalan-based linguistic models. The method followed was to apply a taxonomy of the sociopragmatic level of academic language (Henrichs, 2010) to determine the quality of the conversational style and intersubjective cooperation found in the discourse. The results indicate that CLIL classroom discourse is characterised by the sort of conversational style that facilitates the development of academic language skills. However, in terms of intersubjective cooperation the results are somewhat inconclusive. Based on these results, the study suggests raising awareness of the role of conversational style in classroom discourse so as to boost the quality of teacher-student interactions in primary-school CLIL contexts and, thus, contribute to an identified need for continuous improvement of CLIL pedagogies and teacher training (Lorenzo, 2007; de Graaff et al., 2007).
\end{abstract}

Keywords: CLIL, primary education, classroom discourse, academic language skills, sociopragmatics, multilingualism

\section{Introduction}

Content and Language Integrated Learning (CLIL) has been readily adopted throughout Europe, as it appears to comply with European Union policies regarding multilingualism (i.e.: the $1+2$ policy - European Commission, 1996). From an applied linguistics perspective, one of the main issues to address is whether CLIL leads to faster and better attainment of foreign/second language (FL/L2) competences than other, more traditional, educational models (Ruiz de Zarobe \& Jiménez-Catalán, 2009). It is claimed that CLIL offers realistic and naturalistic ways to learn additional languages (Marsh, 2008). In fact, studies which have investigated the impact of CLIL programmes on FL/L2 proficiency (Jiménez-Catalán, Ruiz de Zarobe \& Cenoz, 2006; Jiménez-Catalán \& Ruiz de Zarobe, 2007; Ruiz de Zarobe, 2008) indicate that, in various competence areas, CLIL students have an advantage over students from other programmes, such as English as a Foreign Language (EFL). Additionally, it is supposed that CLIL contexts provide young language learners with not only linguistic proficiency but also "the associated content knowledge and skills needed/required for a globalized world" (Anderson, McDougald \& Cuesta Medina, 2015, p.138 - our emphasis). In this sense, the concept of academic language skills comes into play. Llinares (2015), following Halliday (1994), points out that CLIL learners are expected to be able to use their FL/L2 linguistic resources to fulfil three distinct functions; ideational (expression of academic knowledge), interpersonal (appraisal of said knowledge and social participation in the classroom), and textual (production of and distinction between written and oral texts). Each of these functions supposes the use of academic language skills. It is important to assess the potential for the development of such skills provided by current FL/L2 
learning contexts because, in the past, traditional language-teaching methods have "often dissociate[d] language learning from cognitive or academic development" (Snow, Met \& Genesee, 1989, p.202). Nevertheless, the work that examines the potential of CLIL contexts to develop academic language skills remains quite novel and relatively scarce. Exploring academic language development necessarily involves looking at the quality of that language, its function, and its appropriate deployment in different academic contexts. For that reason, it is logical that existing studies exploring academic language in CLIL settings do so from a pragmatics perspective. However, much of this research takes a pragmalinguistic approach. To date, there are no studies which take a sociopragmatic approach to analysing the communicative intentions behind the types of discourse and interaction in the CLIL classroom that may favour the development of academic language skills in early FL learners. The current study attempts to do precisely that, thus making a further contribution to our understanding of CLIL settings, especially the improvement of teacher training and pedagogies (Lorenzo, 2007; de Graaff et al., 2007), as well as the burgeoning field of multilingual pragmatics (Safont, 2018).

\subsection{Pragmatics of CLIL}

The pragmatics of CLIL contexts remains a relatively under-researched area (Nashaat Sobhy, 2017), and whether pragmatic competence is an outcome is still subject to some debate (Dalton-Puffer, Nikula \& Smit, 2010; Ruiz de Zarobe, 2011). There are a number of European studies in this vein that focus on classroom discourse but most of them focus on the analysis of specific speech acts. For example, Nikula (2002) found that, in both CLIL and non-CLIL classrooms, teachers did not focus on pragmatic aspects of language use and students were not often exposed to modified ways of speaking because the teachers favoured very direct strategies. She concludes that lack of pragmatic marking may represent a characteristic of classroom settings rather than a problem in interaction, and proposes that classrooms should be "studied as social contexts in their own right" in order to better understand "the features of language and interaction that have significance in them" (Nikula, 2002, p. 464). Dalton-Puffer and Nikula (2006) discovered two contextual factors that influenced the use of directives for both teachers and students: the object of the directive and the classroom register. Directives for information were less mitigated because they were seen to be sanctioned by the educational context of the classroom, while directives for action required more interpersonal work. Similarly, directness was less frequently mitigated in the instructional register than in the regulative register. From this, they conclude that CLIL classrooms have "specific institutional constraints on discourse practices" (Dalton-Puffer \& Nikula, 2006, p. 263). Nikula (2008) explored the ability of CLIL students "to use language in ways that both reflect and (re)create the [institutional] roles as teachers and students" (Nikula, 2008, p. 99). Results reveal that in interpersonal concerns, such as negotiating disagreements and misunderstandings, students are able to monitor their directness in spite of lacking native-like pragmatic competence. The author suggests that CLIL students present a more positive image of pragmatic skills than their EFL counterparts, because "there is a difference between pragmatic meaning making as something that is considered in the abstract, and as something that has a direct bearing on how one is perceived as a social actor" (Nikula, 2008, p. 109). Lastly, while the above studies focus on pragmatics as a discourse feature of CLIL contexts, Nashaat Sobhy (2017) presents a study of pragmatic competence as a consequence of CLIL programmes. She focused specifically on how secondary-school students acquired request modifiers and strategies as a result of increased exposure to English through CLIL. Her results indicate that while learners can acquire modification devices in spite of no formal instruction in pragmatics, they are not able to use them properly, often mixing softeners and aggravators (which she refers to as 'pragmatic bipolarity'). The studies mentioned above paint a picture of CLIL settings as a specific social context subject to institutional constraints, and in which students can not only learn certain pragmatic features incidentally, but can also attempt to use them to position themselves as social actors. However, this work does not explore the possibility for the development of academic language skills.

\subsection{Academic Language Skills}

The academic language register is associated with the linguistic features of academic disciplines (Scarcella, 2003), or more specifically "the form of language expected in contexts such as the exposition of topics in the school curriculum, making arguments, defending propositions, and synthesizing information" (Snow, 2010, p.450). Studies show that basic academic language skills begin to develop in infancy and continue increasing in complexity through childhood, adolescence, and into adulthood (Gibbons, 1998; Nippold et al, 1999; Benelli et al, 2006; Snow, 2014; Henrichs \& Leseman, 2014). The way that general language skills are developed in the social environment is one of the earliest predictors of successful academic language use later in life. The social context shapes and supports early language development in various ways (Hoff, 2006). For instance, contact with academic-style materials (i.e.: books) is beneficial because it involves a larger vocabulary, more complex structures, more questions, and more talk about language (metalanguage). Moreover, opportunities to communicate depend on the extent of the mutual engagement between a young learner and a significant adult. 
Mutual engagement may arise from the communicative functions of speech, specifically the extent to which conversation is elicited. Conversely, strong directive and regulatory conversation styles have been shown to negatively affect lexico-grammatical development; thus, the quality of the input may help or hinder language development (Kloth et al., 1998). Uccelli et al. (2015) point out that language development is a life-long process, as individuals have to continually navigate new social contexts. As language and social context are inseparable, language learning is the result of each individual's socialisation and enculturation trajectory. However, skilful language use in one context does not automatically translate to proficiency in other contexts. In an educational environment, this means that although a student may have been socialised into effective colloquial communication strategies, they may find successful participation in academic discourse greatly challenging. This is because instructional discourse in a school context frequently involves conveying messages which are cognitively complex (Henrichs, 2010) and often require students to understand the world "beyond the here and now" (Snow et al., 1995, p. 38); that is, in a more abstract and decontextualised way. Therefore, it is important to explore early institutional settings because young learners who have not already been inducted into oral academic language will find it enormously challenging to use later on in more advanced educational tasks (Snow, 2010, 2014). In this vein, Snow and Uccelli (2009) put forward a pragmatic-based approach, which recognises that "language forms represent conventionalized solutions to communicative challenges" (Snow \& Uccelli, 2009, p. 122). They propose that academic language corresponds to two communicative tasks: representing the self and the audience, and then representing the message (which, in turn, involves organisation of discourse). In this sense, the challenge is to identify the audience, and then initiate and maintain the appropriate relationship between audience and self. At the school level, this is of great importance in the first stages of developing academic language skills, since students have to learn to "suspend their personal relationship with the teacher" (i.e.: ignore their knowledge of what the teacher already knows), in order to "imagine a nonfamiliar audience with high levels of language but without specific knowledge of the target topic" (Snow \& Uccelli, 2009, p. 124). After establishing an appropriate relationship, students must also be aware that meaning comes not just from what they say, but also how they say it. In this way, they must use forms of language that perform specific functions (i.e.: display and convey knowledge) suitable for the academic community in which they are operating. The studies above indicate that academic language skills grow and develop across the lifespan in order for learners to solve increasingly complex communicative challenges in increasingly formal settings. However, this work only considers academic language itself and the functions of academic language; there is no focus on the communicative intentions behind the utterances in classroom discourse, and how classroom interaction may facilitate a mutual goal (i.e.: the co-construction of knowledge).

\subsection{The Sociopragmatic Level of Academic Language}

One study which actually focuses on such intentions is Henrichs' (2010) taxonomy of the sociopragmatic level of academic language. The taxonomy focuses on two specific variables: conversational style and intersubjective cooperation. The former refers to "the speech act choices interlocutors make in order to realise their communicative intentions", while the latter refers to "the way in which interlocutors complement each other in order to arrive at a mutual goal" (Henrichs, 2010, p. 143). Conversational style is operationalised through a codification of speech acts (based on: Searle, 1979; Bach \& Harnish, 1979). In terms of instructed contexts, the two most characteristic speech acts are assertives (statements) and directives (instructions and questions). Since conveying knowledge is the assumed goal of academic language, it is common to find the use of statements. In this sense, assertive speech acts form a fundamental part of the academic register, and, accordingly, constitute the first category of the taxonomy. Conversely, the second category of the taxonomy deals with directive speech acts and is divided into three sub categories. Instructions, usually expressed in the imperative, are frequently used in classroom contexts in order to give assignments or orders; thus, simple directives constitutes the first sub category. Moreover, questions are also a common feature of classroom contexts. The taxonomy distinguishes between closed questions, which could be answered with a simple 'yes' or 'no', and open-ended questions, which could have any other answer. The taxonomy only considers the latter to form part of the academic register, since they are "considered efficient tools for conversation elicitation" (Henrichs, 2010, p. 146). In this sense, the second and third sub categories of directives are open-ended questions and closed questions, respectively. Additional speech acts that can frequently be observed in classroom contexts are commissives (announcements, promises, threats, and warnings) and expressives (congratulating, apologising, and deploring). Accordingly, these speech acts, alongside short utterances called minors (i.e.: yes, no, okay, etc.) were grouped together to make up the final category of the taxonomy (Other). The following extract, adapted from Henrichs (2010, p. 155), shows a typical example of conversational style realised through speech acts in an instructional activity in a classroom context: 
Table 1. Example of conversational style

\begin{tabular}{ll}
\hline Interlocutor and utterance & Conversational style \\
\hline T: We're going to fold a (paper) fish. & other: commissive \\
\hline T: A fish fish in the water. & other: song \\
\hline T: So we need two pieces of paper to fold. & assertive \\
\hline T: A big one and a small one. & assertive \\
\hline T: First we take a big one. & assertive \\
\hline T: David, which one do you want? & open-ended question \\
\hline T: Choose one, a big one. & directive \\
\hline S: Red. & assertive \\
\hline T: Red, good. & other: repetition \\
\hline
\end{tabular}

The second variable in the taxonomy is intersubjective cooperation, which is defined as "the dynamic process by which two individuals co-construct meaning and knowledge" (Henrichs, 2010, p. 166). This process is constantly ongoing in conversation and is characterised by the extent to which new elements are introduced, existing elements are built upon, new information is elicited, and feedback is given; for this reason, we consider the variable complementary to conversational style. Three types of behaviour associated with intersubjective cooperation are distinguished in the taxonomy: 1) verbal expansions, which build on and expand existing discourse - they include paraphrasing, repetitions, and requests for new information; 2) verbal extensions, which add a new element to the conversation - they enrich the discourse with new thoughts, ideas, or arguments; and 3) procedural utterances, which are task-facilitating rather than conversation-eliciting - they include short repetitions and utterances to direct behaviour/initiate tasks. The following extract, adapted from Henrichs $(2010$, p. 172), shows a typical example of intersubjective cooperation and its associated behaviours in a classroom context:

Table 2. Example of intersubjective cooperation

\begin{tabular}{lll}
\hline Turn & Interlocutor and utterance & Behaviour \\
\hline 01 & T: Now Dylan can tell something. & procedural \\
\hline 02 & S: When I get home, then I might go with mummy to the [woods] if mummy wants to. & extension \\
\hline 03 & T: This afternoon? & extension \\
\hline 04 & S: Maybe. & expansion \\
\hline 05 & T: And what are you going to do in the [woods] then? & expansion \\
\hline 06 & S: Play, and play with the little animals. & extension \\
\hline
\end{tabular}

When the taxonomy was applied to actual classroom discourse, assertives were expected to be the main speech act that would distinguish between academic and informal registers in classroom contexts. Nevertheless, the study found that "question-asking fulfils this differentiating role"; specifically, the rate of open-ended questions (Henrichs, 2010, p. 166). Furthermore, regarding intersubjective behaviours, the author observed that classroom conversation was scaffolded by teachers "through a combination of expansions and extensions", and that the extensions were intended "to ensure that the child's contribution contains all necessary information for the other children to understand" (Henrichs, 2010, p. 178). Thus, the study indicates that the communicative intentions underlying classroom discourse may play an important role in the early development of academic language skills. However, this work only considers the development of such skills in the L1; academic language skills present a different set of challenges for FL/L2 learners (Cummins, 1979, 2000), and thus require exploration in these contexts.

\subsection{Academic Language Skills in CLIL and Non-CLIL Settings}

Non-CLIL settings, such as EFL classes, tend to show a number of characteristics which may not be beneficial in the development of academic language skills. Learners may find that certain features that are prevalent in EFL classrooms can restrict their choice of language. According to Walsh (2002), in EFL contexts, teachers tend to 
control the topic of the discussion, the content and procedure, as well as who is allowed to participate and when. Moreover, the role of the teacher is dominant, in the sense that they take responsibility for managing the interactions. Teachers do most of the talking and frequently modify their talk to the students. The students, in turn, take their cues from the teacher although they rarely modify their speech. Finally, it is the teacher who asks most of the questions; questions to which they usually already know the answers (display questions). Garton (2012) agrees that teacher-fronted interaction may limit learners' contributions. Citing van Lier (1996), she points out that the "asymmetrical relationship between teachers and their students may be advantageous in terms of control and efficiency but the cost is a limitation of learner participation, expressiveness, and employment of initiative and self-determination" (Garton, 2012, p. 30). On the contrary, several studies indicate that CLIL contexts have the potential to facilitate the development of academic language skills. Dalton-Puffer (2007, p. 127) argues that "CLIL classrooms are academic environments, and academic language will [...] be available in the input and required as output"; although her study actually revealed a scarcity of academic language functions in the classroom discourse, which may be attributable to a lack of declarative knowledge about such functions on behalf of the teachers. Nikula (2007) points out that CLIL lessons have the advantage over EFL lessons, since they provide more opportunity to practice the academic language skills involved in argumentation. Moreover, studies have shown a clear predominance of open-ended questions in CLIL environments (Dalton-Puffer, 2007; Pasqual Peña, 2010); as mentioned above, open-ended questions are regarded as a 'conversation eliciting' strategy, and are thus claimed to contribute towards the development of language skills in general (Hoff, 2006), and academic language skills in particular (Henrichs, 2010). Dalton-Puffer (2008) explains the domain-specific vocabulary benefits of CLIL, stating, "through studying content subjects in the foreign language CLIL learners possess larger vocabularies of technical and semi-technical terms and possibly also of general academic language which gives them a clear advantage over their EFL-peers" (Dalton-Puffer, 2008, p. 145 - our emphasis). Marsh (2008) claims that, through its focus on content teaching, CLIL environments can help develop higher-order language skills, and that this characteristic is what sets CLIL apart from other content-oriented language-learning approaches. In his view, this is because the instructional content in CLIL teaching comes from academic subjects. It follows then, that if CLIL favours the development of domain-specific vocabulary, critical thinking, and argumentation, it should constitute fertile ground for the development of academic language skills. In fact, regarding the Basic Interpersonal Communication Skills and Cognitive Academic Language Proficiency distinction (Cummins, 1979), it has been noted that the academic content-driven learning settings that characterise CLIL contexts more readily develops the latter (Lorenzo \& Rodríguez, 2014; Lorenzo, 2017), even to the detriment of the former (Llinares, Morton \& Whittaker, 2012). Although this limitation has been a cause for concern for some scholars (see Dalton-Puffer, 2005), in the case of our study it reinforces the fact that the development of academic language skills is likely to be favoured in the CLIL classroom.

\subsection{Study Rationale and Research Questions}

Cenoz, Genese and Gorter (2014) have recommend that CLIL research extend further than FL/L2 proficiency to look at achievement in academic domains. While some studies have already begun to do this (Lorenzo \& Rodríguez, 2014; Lorenzo, 2017), the tendency is to look at the characteristics of the language used in the classroom; in short, a pragmalinguistic perspective. To our knowledge, no studies have considered how the functions of classroom discourse help or hinder the creation of an institutional environment that is conducive to the early development of academic language skills. This reveals a research gap which the current study intends to address. There is a need to focus specifically on comparing the sociopragmatic component of academic discourse in the L3 in CLIL and non-CLIL multilingual primary education environments. The studies outlined in the previous sections point to the advantages of CLIL contexts regarding academic language (Dalton-Puffer, 2007, 2008; Llinares, Morton \& Whittaker, 2012; Lorenzo \& Rodríguez, 2014; Lorenzo, 2017; Marsh, 2008; Nikula, 2007, 2008; Pasqual Peña, 2010). Therefore, we expect that CLIL programmes will favour the types of conversational style and intersubjective cooperation (Henrichs, 2010) that will enhance the development of academic language skills in young learners. Moreover, there is a wide consensus that once cognitive skills have been acquired they can transfer from one language to another (Hamers \& Blanc, 1989; Cummins, 2000), and it has been shown that pragmatic awareness in young multilinguals is contingent on cross-linguistic interaction between their language systems (Safont \& Portolés, 2015). Therefore, we propose that the language in which early academic skills are developed is of secondary concern to the actual development of these skills in an academic setting. With this in mind, we have formulated the following research questions (RQs) to guide the present study:

- RQ1: Are the characteristics of conversational style more favourable to the early development of academic language skills in CLIL or non-CLIL settings? 
- RQ2: Are the behaviours associated with intersubjective cooperation more favourable to the early development of academic language skills in CLIL or non-CLIL settings?

\section{Method}

This section will describe the data collection and method of analysis. As the data were collected from primary schools in a bilingual region of Spain, where English is taught as an L3, it will be beneficial for the reader to understand the peculiarities of this educational context.

\subsection{Sociolinguistic Characteristics of Primary Education}

Primary education, which constitutes the beginning of obligatory schooling in Spain, is carried out in public Colegios de Educación Infantil y Primaria, in private international schools, or in public-private partnerships, known as centros concertados. It is spread across three educational cycles: first $\left(6-8\right.$ years, $1^{\text {st }}$ and $2^{\text {nd }}$ grade), second ( $8-10$ years, $3^{\text {rd }}$ and $4^{\text {th }}$ grade), and third (10-12 years, $5^{\text {th }}$ and $6^{\text {th }}$ grade). In bilingual areas, such as the Valencian Community, local governments have implemented linguistic policies to ensure that both co-official languages are represented in the public education system. In this context, students are obliged to learn both the majority (Spanish) and the minority (Valencian/Catalan) languages, alongside English as a foreign language. The incorporation in 1998 of the Programa d'Educació Bilingüe Enriquit (PEBE) extended the teaching of English, which was already being taught as EFL from the $3^{\text {rd }}$ grade, to cover all six years of primary education. The PEBE greatly increased the amount of school time devoted to teaching both English and Catalan and resulted in the establishment of multilingual schooling in the community (Pinilla-Padilla, 2006; Portolés, 2015).

The current linguistic programmes in infant and primary education are Programa Plurilingüe d'Ensenyament en Castellà (PPEC) and Programa Plurilingüe d'Ensenyament en Valencià (PPEV). In the PPEC, Spanish is the main language of instruction. Catalan and English are taught as language classes and these languages are used as the language of instruction for at least one other subject each. In the PPEV, Catalan is the main language of instruction. Spanish and English are progressively incorporated as language classes and instructional languages in at least one other subject each. In both cases, the exact configuration of languages in the curriculum is left for each school to determine individually; this is referred to as the programa lingüistico del centro (PLC). As for the integration of CLIL into the PLC, this almost always means CLIL in English. The number of CLIL contact hours per week are 1.5 in the first cycle and the language/content balance is more oriented towards language, in the second cycle there are 1.5 hours per week and the balance is fairly equal, and in the third cycle there is 1 hour per week and the balance is slightly biased towards content (Frigols Martín, 2008). Which subjects are taught through CLIL, again, is determined individually by each school. General data and classroom observation indicates that CLIL students have a higher level of English than that of non-CLIL students, and that their level of content achievement is no lower than that of non-CLIL students (Frigols Martín, 2008).

\subsection{Data Collection and Analysis}

Data were collected from four primary schools in the province of Castellón (Spain). Three of the schools are public centres and the other is a centro concertado. Two schools follow the PPEC and the other two follow the PPEV. The researchers were granted access to one class from each school; two EFL classes and two CLIL classes (Science and Technology, and Arts and Crafts) were chosen. The general characteristics of each class are displayed below in Table 3. The students were all in the third year of primary education, except in one case where the researchers could not access the third year class, so a second year class was selected instead. All classes were approximately one hour long, with the exception of one CLIL class that lasted 35 minutes. Each class was video recorded and transcribed for subsequent analysis. In this paper, the data is presented in the original language, inline translations (marked: tran) are provided by the first author.

Table 3. General characteristics of the classrooms

\begin{tabular}{lllll}
\hline Location: & Castelló & Alcora & Burriana & Borriol \\
\hline Students: & 24 & 10 & 28 & 23 \\
\hline $\begin{array}{l}\text { Teacher } \\
\text { experience: }\end{array}$ & Teacher & Training degree & $\begin{array}{l}\text { Teacher Training degree + MA } \\
\text { language acquisition }\end{array}$ & Teacher \\
\hline $\begin{array}{l}\text { Teacher } \\
\text { English: }\end{array}$ & B2 & C1 & Training degree & Training degree \\
\hline Programme: & PPEC & PPEV & C1 & B2 \\
\hline
\end{tabular}




\begin{tabular}{lllll} 
Type: & CLIL & CLIL & EFL & EFL \\
CLIL subject: & (Arts and Crafts) & (Science and Technology) & & \\
\hline
\end{tabular}

To respond to the RQs laid out above, the current study takes the innovative approach of applying a sociopragmatic taxonomy (Henrichs, 2010) to CLIL and non-CLIL classroom discourse in order to analyse its common features. From this theoretical base, we analyse both CLIL and EFL primary school lessons. Furthermore, in line with a multilingual perspective (Jessner, 2008; Cenoz, 2013; Portolés, 2015; Portolés \& Safont, 2018; Safont, 2018; Safont \& Portolés, 2015, 2016), we also compare Spanish-based and Catalan-based educational programmes. We pay specific attention to the qualities of the conversational style and intersubjective cooperation. In a formal setting, such as the institutional setting of the classroom, the goal is to elicit, convey, and monitor knowledge. Thus, it is expected that "a formal conversational style will prevail" (Henrichs, 2010, p. 21), which would be characterised by the use of statements and open-ended questions, as well as intersubjective cooperation patterns that display a high degree of verbal extension behaviour.

Therefore, in order to carry out the analysis, we examine the discourse to determine the presence of the following characteristics. In terms of conversational style, we look for the specific directive type 'open-ended questions' from the teacher, as well as the extent to which they are responded to with assertive speech acts from the students. This allows us to see to what extent the teachers are eliciting conversation from the students, and to what extent the students are thus enabled to convey their knowledge. On the contrary, we identify that a conversational style characterised by simple directives, closed or display questions, and frequent use of the regulatory register may hinder the creation of an environment conducive to the development of academic language skills (Walsh, 2002; Hoff, 2006; Henrichs, 2010). In terms of intersubjective cooperation, we look for evidence of this type of interaction in the discourse and specifically focus on the extent to which the teacher uses verbal expansions as a method of encouraging the co-construction of knowledge and the extent to which they are responded to with verbal extensions by the students. This will allow us to see to what extent the students are able to enrich the classroom discourse with new ideas, thoughts, and arguments, and to what extent the teachers scaffold and support this. We propose that the presence of these specific qualities of classroom discourse will create a suitable environment for the early development of academic language skills.

\section{Results and discussion}

As the current study makes a comparison between, on the one hand, CLIL and non-CLIL (in this study, EFL) contexts, and on the other hand, majority (PPEC) and minority language (PPEV) instruction programmes, the results are presented according to four separate modalities: EFL-PPEC, EFL-PPEV, CLIL-PPEC, and CLIL-PPEV.

\subsection{Conversational Style}

In order to respond to the first research question, we analysed the classroom discourse to determine the presence and extent of open-ended questions from the teachers and assertives from the students. The observations we have been able to make appear to support the proposal that CLIL settings, more so than non-CLIL settings, are characterised by the sort of conversational style that facilitates the development of academic language skills. We make this claim because, in the CLIL classes, we observe a greater use of questions, which allow the students to display knowledge related to the current topic or task. Moreover, when display questions are used in CLIL classes, they aim to elicit domain-specific vocabulary, rather than simply drill vocabulary items. Lastly, in the instructional register, directives tend to be backed up by assertives from the teacher, who also tends to invite participation by using open questions. In contrast, the EFL classes tend to display a more closed conversational style, characterised by directives, commissives, closed and display questions, and frequent use of the regulative register. The overall speech act production by the teachers according to the sociopragmatic taxonomy is displayed below in Table 4 . The remainder of this section provides some examples of conversational style taken from the observed classroom discourse.

Table 4. Use of speech acts by the teacher in each class

\begin{tabular}{lllll}
\hline Speech act & EFL-PPEC & EFL-PPE & CLIL-PPEC & CLIL-PPEV \\
\hline Assertive & 25 & 30 & 32 & 22 \\
\hline Simple directive & 89 & 65 & 38 & 16 \\
\hline Open-ended question & 31 & 22 & 33 & 12 \\
\hline Closed question & 32 & 43 & 17 & 18 \\
\hline
\end{tabular}




\begin{tabular}{lllll}
\hline Expressive & 6 & 16 & 13 & 9 \\
\hline Commisive & 20 & 29 & 26 & 11 \\
\hline Duration of class & $56 \mathrm{mins}$ & $52 \mathrm{mins}$ & $58 \mathrm{mins}$ & $35 \mathrm{mins}$ \\
\hline
\end{tabular}

The conversational style of the teachers in the EFL contexts was marked by heavy use of simple directives, as well as closed and open-ended questions. However, the quality of the open-ended questions must be taken into consideration; they are mainly display questions, such as what colour is X?, what is this?, or what is your name?, or questions that provide limited scope in terms of an answer, such as what is your favourite X? In this sense, we propose that although open-ended questions are frequently observed in EFL contexts, the way in which they are deployed does little to foster the development of academic language skills. Some typical examples of simple directives, used to regulate class behaviour with basic instructions, are come on, sit down, open your books, choose a boy/girl, and silence and listen to me. Some commissives were observed in the sense of committing the teacher or the class to action, such as we'll listen the song, or later I'll say/you have to say.... Other commissives were observed, such as promises, if you're silence and listen to me next class we'll go to the other class, and threats, do you want to stay at the playground with me? Moreover, some use of expressives was also observed, to congratulate, such as very good and excellent, and also to deplore, such as uyyy in English.

Table 5. Example of directives and commissives in the EFL-PPEV class

\begin{tabular}{ll}
\hline Interlocutor and utterance & Speech act \\
\hline T: now, boys and girls listen [1] I'm going to ask you questions [2] and you have & 1: directive \\
to answer me [3] ok. & 2: other: commissive \\
& 3: directive \\
\hline I write here the questions [4]. & 4: other: commissive \\
\hline Alberto, do you want to stay at the playground with me [5]? & 5: other: commissive \\
\hline at the playground? & \\
\hline at the playground do you want to stay with me [6]? & 6: other: commissive \\
\hline S1: estaràs castigat al pati [7] & 8: open-ended question \\
\hline S2: quan? [8] & 9: other: commissive \\
\hline T: tomorrow, or Monday or Tuesday or Wednesday [9]
\end{tabular}

For example, the extract above from the EFL-PPEV class (Table 5), shows an example of simple directive and commissive speech acts. First, the teacher calls the class to attention with a directive [1], then lays out her intention for the activity with a commissive [2], and closes with a directive to instruct the students on what they must do [3]. The teacher uses another commissive to indicate her intention to start the activity [4]. At this point, a student behaves in a way that the teacher deems inappropriate; from here, she begins to use commissives in the regulatory register $[5,6]$ to threaten the students into behaving as she wants them to. S1 explains the threat to the other student, who presumably does not understand, using an assertive [ 7 - tran: you'll be punished at break]; although this utterance may also be intended as a warning. The student responds with a directive requesting information [8-tran: when?], and the teacher follows up with another commissive to reiterate the threat [9]. This use of directives unaccompanied by assertives (to provide supporting arguments) alongside the use of the regulative register to control student behaviour was a consistent feature of the discourse in the EFL classrooms.

It was also observed that the majority of the questions the EFL teachers asked were of a very simple nature (mainly using the auxiliaries can, do, and have), and only allowed for yes or no answers from the students (classed as 'minor' speech acts in the sociopragmatic taxonomy). There are some, albeit very few, attempts to ask more open-ended questions, but these are almost always in terms of what's your favourite X?, which is usually only responded to with a very brief assertive speech act. Furthermore, it is very rare for the teacher to follow up on these responses in order to provide the students the possibility of producing further assertives and thus displaying their knowledge. 
Table 6. Open-ended and closed questions in the EFL-PPEC class

\begin{tabular}{ll}
\hline Interlocutor and utterance & Speech act \\
\hline T: welcome everybody after your holidays, after fallas, ok? & \\
how was fallas? [1] & 1: open-ended question \\
it was ok? [2] & 2: closed question \\
\hline Ss: ye::s & \\
\hline
\end{tabular}

For instance, the extract from the EFL-PPEC class (Table 6), shows how the teacher welcomes the class and asks them if they enjoyed fallas (a traditional Valencian festivity). However, without allowing any time for the students to even attempt a response to the conversation-eliciting, open question, how was fallas? [1], she immediately follows up with the closed question, it was ok? [2]. This leaves the students to respond to the closed question (with a minor), rather than attempt to formulate a response to the conversation-eliciting one (with an assertive). Of course, while we can assume it unlikely that 8-year-old EFL students would formulate particularly complex responses to the conversation-eliciting question, the somewhat closed conversational style of the teacher eliminates any possibility of a more complex response.

Table 7. Examples of display questions in EFL classes

\begin{tabular}{ll}
\hline $\boldsymbol{E F L}-\boldsymbol{P P E} \boldsymbol{V}$ & $\boldsymbol{E F L - P P E C}$ \\
\hline T: and today is::: & T: guys, now are you wearing, wearing socks, now? \\
is today Monday? & $(1.0)$ you, are you wearing socks? no? \\
boys and girls, is today Monday? & S: no? \\
Ss: no::: & T: I can see that you're wearing socks \\
T: it's today Tuesday? & S: (xxx) \\
Ss: no::: & S2: ¿tienes calcetines? \\
T: is today Wednesday? & T: ok, ok, yes you're right, ok (.) err, Pepe, are you \\
Ss: no::: & wearing socks? \\
T: is today Friday? & S: yes \\
Ss: yes::: & T: yes, I am (.) repeat \\
[no::: & S: yes, I am \\
Sx: ho has mesclat & T: yes, I am (.) Jose are you wearing socks? \\
T: ok, it's today Thursday? & \\
Ss: yes::: &
\end{tabular}

In the extract above (Table 7), further examples of closed questions in the EFL classes can be seen. In the case of the EFL-PPEV class, the teacher makes use of closed, display questions essentially to drill vocabulary regarding the days of the week. In the case of the EFL-PPEC class, the teacher even answers one of her own display questions on behalf of the students: the closed-question directive, are you wearing socks?, followed by the assertive, I can see that you're wearing socks. In both cases, the conversational style of the teacher restricts the contributions of the students to minors and thus limits their ability to convey knowledge. It is clear from these examples, that in the EFL modality, the teacher does most of the talking and frequently controls who gets to speak and when (Walsh, 2002); this asymmetrical relationship will limit participation and initiative on behalf of the students (Garton, 2012). 
Table 8. Display questions in CLIL-PPEV class

\begin{tabular}{ll}
\hline Interlocutor and utterance & Speech act \\
\hline T: and now, we're going to review the computer [1], ok? & 1: other: commissive \\
\hline T: do you remember the parts of a computer? [2] (1.0) & 2: closed question \\
\hline Sx: err, yes (1.0) & 3: directive \\
\hline T: let's- let's say them [3] (1.0) & 4: directive \\
\hline T: come on [4] & 5: assertive \\
\hline S1: err, yo me sé una (1.0) computer [5], ay, a::y & 6: assertive \\
\hline S2: c- car ((teacher leans forward to listen)), car [6] & \\
\hline T: no ((points to other student)) & $7:$ directive \\
\hline S3: (xxx) & $8:$ assertive \\
\hline T: the part of a computer ((points at book)) [7] (1.0) & $9:$ assertive \\
\hline S4: err, oh, screen, screen [8] & \\
\hline T: no, you mean printer [9] & $10:$ assertive \\
\hline S4: printer & $11:$ open-ended question \\
\hline T: mouse, printer, mouse, [10] what else [11]? ((points to student)) (2.0) & \\
\hline T: no? & $12:$ assertive \\
\hline Sx: cristal [12] & \\
\hline T: no & $13:$ assertive \\
\hline Sx: jo pense per [13] (xxx) & $14:$ directive \\
\hline T: Aline [14] & $15:$ assertive \\
\hline S5 : glass [15] & $16:$ assertive \\
\hline T: no, these are materials [16], ok, let's review [17] & \\
\hline
\end{tabular}

The CLIL-PPEV class is also characterised by a number of different display questions, such as does it need electricity? or is it simple or complex? (referring to images of machines projected onto the whiteboard). However, the display questions in this modality are different to the EFL modalities because they aim at eliciting knowledge of one aspect of the topic. For example, in the extract above (Table 8), the teacher already knows the answer to the questions. Nevertheless, the students in this CLIL class are required to demonstrate knowledge in a specific domain (technical and semi-technical terms - Dalton-Puffer, 2008), rather than the teacher simply checking comprehension of vocabulary items in a decontextualized manner, as can be seen in the EFL display question examples. In this case, the conversational style of the teacher allows more opportunities for the students to perform assertives [5, 6, 8, 12, 13, and 15] and thus convey their knowledge of the topic, even though their attempts are not always correct. In contrast to the display questions that can be observed in the EFL modalities, the conversation is not dominated by the teacher (Walsh, 2002; Garton, 2012), and this leads to a more symmetrical interaction (Nikula, 2007). In this way, the CLIL class appears to more readily encourage the students to ignore their knowledge of what the teacher already knows (Snow \& Uccelli, 2009) in order to convey knowledge. 
Table 9. Giving instructions in the CLIL-PPEC class

\begin{tabular}{ll}
\hline Interlocutor and utterance & Speech act \\
\hline T: first I'm going to explain the arts and crafts activity for today [1] & 1: other: commissive \\
\hline Ss: ok & \\
\hline T: so please leave the book and listen to me [2] (2.0) I think it's page 41 (1.0) do & 2: directive \\
you have it all correct? [3] perfect & 3. closed question
\end{tabular}

Sx: yes

T: forty-one (2.0) this is going to be really really tricky [4], a little bit difficult work for today, why? [5] because we are going to use an unusual thing, we are only going to use the scissors, the glue, and we are going to take here that I have [6], look at this [7], that you know the name [8], I have here a lot of? [9]

4: assertive

5: open-ended question

6: other: commissive

7: directive

8: assertive

9: open-ended question

\begin{tabular}{ll}
\hline Ss: err, papers [10] & $10:$ assertive \\
\hline Sx: newspapers [11] & $11:$ assertive \\
\hline T: no newspapers [12] (2.0) & $12:$ assertive
\end{tabular}

Ss: err

$\mathrm{T}$ : magazines (1.0) the magazines is not for look the pictures and to read [13], ok? 13: directive

Ss: ok

T: we have to- (xxx) I am speaking ((reprimands student)) [14] thank you, we have to try to look for colours [15] (1.0) ok? different kind of colours, for example here we have this colours, here we have the blue the black, bit of here green, this grey, for example here you have a lot of colours [16], so what we are going to do is [17]- what are we going to do with the pages and the colours? what do you think? [18] (2.0)

Sx: errr, stick, stick [19]

14: directive

15: directive

16: assertive

17: other: commissive

18: open-ended question

19: assertive

T: we have to cut it and we have to stick it [20], but we are going to cut the colours as this? [21] what do you think? [22] for example here I have this blue [23] because I love it [24]so I am going to use it (1.0) and I am going to do this [25], I cut it and now I stick it like this [26], what do you think? [27] it will be correct or incorrect? [28]

\section{0: directive}

21: closed question

22: open-ended question

23: assertive

24: other: expressive

25: other: commissive

26: assertive

27: open-ended question

28: closed question

Ss: incorrect [29]

29: assertive

T: why? what we have to do? you have to do a little? [30]

30: open-ended question

Ss: pieces [31]

31: assertive

$\mathrm{T}$ : Ok, and let's try to put it all in order to complete the picture [32], ok?

32: directive

Ss: ok

In the CLIL-PPEC class, the teacher-student interaction was quite limited; mainly, initiating and monitoring the activity (Arts and Crafts), as well as checking homework from a previous activity (Music). In terms of the 
conversational style of the teacher, in the extract above (Table 9), we can see a clear prevalence of directives, followed in frequency by assertives, and then commissives. In total, there are sixteen directives in this extract; four of them pertain to the regulatory register $[2,7,13$, and 14], three pertain to the instructional register $[15,20$, and 32], six are open questions [5, 9, 18, 22, 27, and 30], and three are closed questions [3, 21, and 28]. After performing the first open-question directive [5] the teacher does not allow the students any time to answer. She immediately continues with a commissive, committing the class (and herself) to future action (how they are going to perform the task). Nevertheless, other open-question directives [specifically 9, 18, 27, and 30] allow the students to respond with assertives $[10,11,19,29$, and 31]. There are some other interesting features of the teacher's conversational style that are worthy of note. In the second long turn by the teacher, she continues with the activity instructions using the commissive (what we are going to do is-) [17] when she stops herself in mid-sentence and reformulates to the conversation-eliciting open questions (what are we going to do with the pages and the colours? what do you think?) [18]; in this way, the teacher positions the students as 'knowledgeable others' (Henrichs, 2010), thus perceiving them as 'social actors' in the academic context (Nikula 2008). Likewise, she follows the closed question (we are going to cut the colours as this?) [21] with the open question (what do you think?) [22]. However, the open question (what do you think?) [27] is immediately followed by the closed question (it will be correct or incorrect?) [28]. On the whole, the teacher attempts to elicit knowledge from the students through open-ended questions, although she is not always consistent in this regard. In this way, the interaction pattern generally follows what we have identified from the sociopragmatic taxonomy as a conversational style that favours the early development of academic language skills.

\subsection{Intersubjective Cooperation}

Moving on to the second research question, in order to respond to this, we analysed the classroom discourse to determine the use of verbal expansion behaviour patterns from the teachers that scaffold the students participation and encourage the co-construction of knowledge. The observations we have been able to make on the type of intersubjective cooperation that facilitates the development of academic language skills are somewhat inconclusive, but they may point to the possibility of an impact deriving from the linguistic programme rather than the setting being CLIL or non-CLIL. We make this claim because, the most effective interactional pattern was observed in the CLIL-PPEV class. Moreover, although the EFL classes were generally very teacher-lead, the EFL-PPEV class also displayed a very effective sequence in which the teacher supported higher-order language skills and co-constructed knowledge with the students through the multilingual practice of translanguaging. The remainder of this section provides some examples of intersubjective cooperation from the observed classroom discourse.

The first thing to note is that there were not many examples of intersubjective cooperation in any of the classes we observed, and they were extremely limited in the EFL-PPEC class. This is because the teacher tends to repeat the same question to different students and, therefore, does not really support the co-creation of knowledge with any one of them.

Table 10. Intersubjective cooperation (lack of) in EFL-PPEC class

\begin{tabular}{lll}
\hline Turn & Interlocutor and utterance & Behaviour \\
\hline 01 & $\begin{array}{l}\text { T: we have trousers here ((teacher writes on board)), come on, more, more, more, I want } \\
\text { to write more (.) come on, tell me }\end{array}$ & procedural \\
\hline 02 & S1: $(x x x)$ & extension \\
\hline 03 & T: no, another one, different one, different one & procedural \\
\hline 04 & S1: otra vez (1.0) & extension \\
\hline 05 & S2: dress & extension \\
\hline 06 & T: dress, ok (2.0) a dress, Pablo, are you wearing a dress? & expansion \\
\hline 07 & S3: no & extension \\
\hline 08 & T: no, I'm not, no, I'm not, err, Carolina, are you wearing a dress? & expansion \\
\hline 09 & S4: yes & extension \\
\hline 10 & T: yes, I am $(x x x)$ another one & procedural \\
\hline 11 & S5: a jumper & extension \\
\hline
\end{tabular}


In this extract from the EFL-PPEC class (Table 10), we see that the teacher displays mainly procedural behaviour (to move the activity forward) and also some expansion behaviour (to ask for more information). However, the teacher's expansions (turns 06 and 08) are both directed at a new student. The students, for their part, are able to extend the discourse but their contributions are limited to minors (turns 07 and 09 ) in response to the expansions by the teacher. In fact, the students only produce assertives (turns 05 and 11) in response to the procedural behaviour of the teacher. The type of behaviour that can be observed in this teacher-lead interaction severely limits the potential for participation from the students (Walsh, 2002; Garton, 2012), and means that the discourse is not scaffolded in a way that would promote the early development of academic skills (Henrichs, 2010).

Table 11. Intersubjective cooperation in EFL-PPEV class

\begin{tabular}{|c|c|c|}
\hline Turn & Interlocutor and utterance & Behaviour \\
\hline 01 & T: and now for an example, Jaume what's your favourite animal? & procedural \\
\hline 02 & $\mathrm{~S}$ : my favourite animal is $\mathrm{mmmmm}$ & expansion \\
\hline 03 & T: horse, bird, cat, dog, snake, spider, & extension \\
\hline 04 & S: spider & expansion \\
\hline 05 & $\mathrm{~T}$ : spider is your favourite animal? are you sure? & expansion \\
\hline 06 & S: com els hamsters no se com se diuen... & extension \\
\hline 07 & T: hamster is hamster, ok so:: & expansion \\
\hline 08 & $\mathrm{~S}: m i$ favourite animal is hamster & expansion \\
\hline 09 & $\mathrm{~T}$ : do you have a hamster? & expansion \\
\hline 10 & S: yes & expansion \\
\hline \multirow[t]{2}{*}{11} & T: big or small? ((S does not understand)) & extension \\
\hline & T: big or small? ((T gesticulates)) & \\
\hline 12 & S: small & expansion \\
\hline 13 & T: and which's colour? red? blue? & extension \\
\hline 14 & S: mmm el gris com se diu el gris? & extension \\
\hline 15 & T: gray ((T writes on the black board $))$ & expansion \\
\hline 16 & S: i la cara és naranja & extension \\
\hline 17 & $\mathrm{~T}$ : orange face? orange face? & expansion \\
\hline 18 & $\mathrm{~T}$ : hamster is a girl or a boy? & extension \\
\hline 19 & S: a boy & expansion \\
\hline
\end{tabular}

The EFL-PPEV class fared slightly better, as the extract above shows (Table 11). The teacher initiates the activity with a procedural utterance (turn 01), the Student attempts to answer but really just starts to reformulate the question using a verbal expansion before getting stuck (turn 02). The teacher then uses a verbal extension to provide new ideas (turn 03); again, the student uses an expansion to select a response from the information that the teacher has provided (turn 04). The teacher attempts to elicit more information from the student with another expansion (turn 05), to which the student responds by introducing a new idea with an extension (turn 06 - tran: as I don't know how to say hamster...). The teacher expands again to provide the vocabulary for the student (turn 07) and the student attempts to reformulate the teacher's contribution with another extension (turn 08). The exchange continues in a similar manner, the teacher expands (turns 09,15, and 17) and extends (turns 11,13, and 18) the discourse. The student, in return expands (turns 10, 12, and 19) and extends the discourse (turns 14 - tran: grey, how do you say grey?, and 16 - tran: and its face is orange). What we observe here is that it is mostly the teacher who performs the verbal extensions (four in total), introducing new arguments to the discourse for the student to choose from. In the turns where it is the student who performs the verbal extensions (three in total), he does so exclusively in L1. The teacher does not attempt to suppress the use of L1 in the classroom, and this allows the 
student to convey some knowledge. However, it is mainly the teacher enriching the discourse with new thoughts. Due to the teacher-led nature of the interaction (Walsh, 2002; Garton, 2012), we consider this example of intersubjective cooperation limited in its potential to develop academic language skills.

Table 12. Intersubjective cooperation in CLIL-PPEC class

\begin{tabular}{lll}
\hline Turn & Interlocutor and utterance & Behaviour \\
\hline 01 & T: did you finish? & procedural \\
\hline 02 & S: yes & expansion \\
\hline 03 & T: what is this letter? & extension \\
\hline 04 & S: uve & procedural \\
\hline 05 & T: vee? & expansion \\
\hline 06 & S: yeah, vee & expansion \\
\hline 07 & T: and this is a oh? & expansion \\
\hline 08 & S: ((student looks)) err? & extension \\
\hline 09 & T: dru::m:: (.) and here? & procedural \\
\hline 10 & S: rush & extension \\
\hline 11 & T: rush? & expansion \\
\hline 12 & S: me lo ha dicho Alvaro & extension \\
\hline 13 & T: no, but it's dru::m (1.0) & expansion
\end{tabular}

In the CLIL-PPEC class there was very little interaction that displayed intersubjective cooperation behaviours. In the extract above (Table 12), the teacher interacts with a student while checking his homework from the previous class (Music). The teacher initiates the task with a procedural utterance (turn 01), to which the student responds with an expansion (turn 02). The teacher then builds on the discourse by requesting new information using an expansion (turn 03), to which the student responds with an extension (turn 04). The next turn by the teacher must be considered a procedural utterance because in the previous turn the student answered in Spanish (uve $=$ the letter $\mathrm{V}$ ), the teacher repeats this in English with a rising intonation (turn 05) in order to direct the student's behaviour to a response in the TL, which the student obliges (turn 06). The teacher continues expanding (turns 07 and 09) until the student extends with new information (turn 10). Again, the next turn by the teacher must be considered procedural because she repeats what the student has said with a rising intonation (turn 11) in order to direct him to reformulate his previous response. This intention fails, however, and the student reverts to L1 in an attempt to excuse his error (turn 12 - tran: Álvero told it to me). The teacher then clarifies the earlier discourse with and expansion (turn 13) and provides new information about the topic with an extension (turn 14), before using another expansion to request new information from the student (turn 15). However, the student remains silent and the teacher continues to provide new information with another extension (turn 16). We can see that the teacher makes a number of attempts to use expansion behaviour to elicit from the student new ideas in the form of extensions. The student does perform extensions but they are either in L1, incorrect, or not relevant to the topic; it is the teacher who makes the only relevant extensions. 
Table 13. Intersubjective cooperation in CLIL-PPEV class

\begin{tabular}{|c|c|c|}
\hline Turn & Interlocutor and utterance & Behaviour \\
\hline 01 & T: a clothes peg (.) is it simple or complex? & procedural \\
\hline 02 & SS: simple & expansion \\
\hline 03 & T: how many parts (.) can you see? & expansion \\
\hline \multirow[t]{5}{*}{04} & Sx: two & extension \\
\hline & SS: [three & \\
\hline & SS: [two & \\
\hline & SS: [three::: & \\
\hline & Sx: three & \\
\hline 05 & T: and what is it made of? (2.0) & expansion \\
\hline 06 & T: do you remember? the materials? & procedural \\
\hline 07 & S1: metal & extension \\
\hline 08 & T: metal (.) and? ((pointing to whiteboard)) what? & expansion \\
\hline \multirow[t]{2}{*}{09} & Sx: wod & extension \\
\hline & SS: [wood, wood & \\
\hline 10 & T: wood (.) excellent & expansion \\
\hline
\end{tabular}

In this example from the CLIL-PPEV class (Table 13), we see an instance of intersubjective cooperation which facilitates the building of domain-specific TL vocabulary (in this case, machines and materials). Preceding this sequence the teacher has used a drill-type exercise with a visual aid to explain to the class that simple machines have one or two parts and complex machines have more. The teacher then initiates the next part of the task with a procedural utterance (turn 01). However, as the teacher's question requires the students to make a choice between two options, their response (turn 02) can only be considered an expansion of the preceding discourse. The teacher then uses a verbal expansion to continue the exercise (turn 03). The students respond with a verbal extension which enriches the discourse with new information (turn 04); they are not sure if the clothes peg has two or three parts but, in the end, they settle on three. The teacher continues the exercise with another verbal expansion (turn 05) but, as this marks a shift in the topic from machines to materials, the students hesitate, leading the teacher to resort to another procedural utterance to facilitate the task (turn 06). One student responds, enriching the discourse with a new thought by means of a verbal extension (turn 07), to which the teacher confirms and furthers the exercise with another verbal expansion (turn 08). Again, the students respond with a verbal extension which enriches the discourse with new thoughts (turn 09). Ending the sequence, the teacher uses another verbal expansion to confirm the response and then congratulate the students (using an expressive speech act). Although instances of this type of interaction were scarce in the CLIL classroom, what we see above faithfully follows the 'expand, extend, expand, extend' teacher-student interaction sequence that we propose facilitates the early development of academic language skills (Henrichs, 2010), specifically semi-technical terms (Dalton-Puffer, 2008). It would thus appear that the interactional behaviour in this CLIL classroom, as observed through intersubjective cooperation, is more symmetrical and allows the students more space to interact (Nikula, 2007).

Table 14. Intersubjective cooperation and translanguaging in the EFL-PPEV class

\begin{tabular}{lll}
\hline Turn & Interlocutor and utterance & Behaviour \\
\hline 01 & T: listen Alberto and Daniel don't sing the song & procedural \\
\hline 02 & S1: Maite no lo entiendo & expansion \\
\hline 03 & S2: a vore primer canteu les xikes $i$ després- & expansion \\
\hline 04 & T: James, James please & procedural \\
\hline 05 & S3: James James. Maite entonces a mi em diuen John & extension \\
\hline
\end{tabular}




06 T: Molt bé Joan expansion

Lastly, in the EFL-PPEV class, we can see an instance of intersubjective cooperation based on classroom translanguaging practice. The extract above (Table 14) shows that the teacher begins the interaction with a procedural utterance in order to facilitate the task (turn 01), which, in this case, is singing a song. A girl in the class requests a clarification of the task by using a verbal expansion (turn 02 - tran: Maite, I don't understand). A boy in the class builds on this discourse by explaining the task using a verbal expansion (turn 03 - tran: let's see, first the boys sing and then-). However, he is cut off, presumably for explaining the task in Catalan, by the teacher, who uses another procedural utterance in an attempt to regain control of the situation (turn 04). Then, another boy in the class enriches the discourse with a new thought by using a verbal extension (turn 05 - tran: Maite, that means they would call me John). The teacher responds to this with a verbal expansion, confirming the student's hypothesis (turn 06 - tran: very good Joan). Here, based on the preceding discourse, S3 has identified that the Catalan name Jaume is James in English, from this he extrapolates the correct hypothesis that his name, Joan, would be John in English. The teacher confirms this hypothesis in Catalan, momentarily breaking the 'English-only' policy she had been maintaining throughout the session. In this instance, we can see how knowledge has been co-constructed through intersubjective cooperation irrespective of the language used, in confirming Joan's observations about the TL the teacher has encouraged the academic language skill of hypothesising. Taking into consideration the transfer of cognitive skills across languages (Hamers \& Blanc, 1989; Cummins, 2000) and the cross-linguistic interaction observed between young multilinguals' language systems (Safont \& Portolés, 2015), we propose that this instance of academic language skills development is peculiar to and dependent on the multilingual nature of the classroom context. It indicates that, if we harness the potential of classroom translanguaging rather than attempting to supress it, we may be able to take advantage of an additional tool to develop higher-order language skills.

\section{Conclusions and Limitations}

By way of a conclusion, our study appears to support the idea that the conversational style (that is, the communicative intentions behind the speech acts) in CLIL settings is more advantageous than in non-CLIL settings in its potential to develop early academic language skills. Moreover, our study may point towards a possible impact stemming from the linguistic programme of the educational centres, as the centres we observed that adopt the PPEV appear to be more effective in promoting the kind of intersubjective cooperation that facilitates early academic language skills. Of the four modalities described above, results from the classrooms observed in our study reveal that, in terms of the sociopragmatic taxonomy of academic language (Henrichs, 2010), the CLIL-PPEV modality presents the most effective setting for promoting academic language skills in primary contexts. As the PPEV is more multilingual than the PPEC, this finding extends earlier research detailing the benefits of multilingual contexts (Jessner, 2008; Cenoz, 2013; Portolés, 2015; Portolés \& Safont, 2018; Safont, 2018; Safont \& Portolés, 2015, 2016), and opens up a new research avenue in this area. We must make it clear, however, that the current study is highly explorative and simply constitutes a first step towards how different conversational styles may have an impact on academic language skills. The above claim, regarding the linguistic programme, is based purely on the classrooms we were able to observe, and, thus, is too limited to allow us to generalise. In order to validate this claim, future research will have to be carried out in a much wider range of classrooms. Furthermore, although the content-driven nature of CLIL settings seem to make them a more academic setting by default, it would seem that the CLIL teachers in our study are not fully capitalising on this potential. Perhaps this is related to what Dalton-Puffer (2007) observed in Austrian CLIL classes, that the teachers lack declarative knowledge of academic speech functions and are not conscious of them as "identifiable and describable" features of classroom discourse (Dalton-Puffer, 2007, p.171). In this sense, one pedagogical implication of the study is the possibility of raising awareness of the role of conversational style in order to boost the quality of teacher-student interactions in primary CLIL contexts. Not only to develop content knowledge and language skills, but also to encourage academic language skills that will grow and develop throughout the students' formal education in response to the increasing complexity of the language they will encounter. In this way, the current study contributes to the continuous improvement of CLIL pedagogies and teacher training, the need for which has been highlighted in earlier research (Lorenzo, 2007; de Graaff et al., 2007). One clear limitation of the current study is that it was only possible to observe four classes. Future research in this vein would benefit from observing a wider range of CLIL subjects and systematically covering all three cycles of primary education in order to make comparisons between subjects and cycles and provide further insights on how the sociopragmatic aspect of CLIL classroom discourse may facilitate the early development of academic language skills.

\section{Acknowledgments}

As members of the LAELA (Lingüística Aplicada a l'Ensenyament de la Llengua Anglesa) research group at 
Universitat Jaume I (Castellón, Spain), we would like to acknowledge that this study is part of a research project funded by (a) the Spanish Ministerio de Economia y Competitividad (FFI2016-78584-P), (b) the Universitat Jaume I (P1·1B2015-20), and (c) Projectes d'Innovació Educativa de la Unitat de Suport Educatiu 3621/18.

We would also like to extend our gratitude to the two anonymous reviewers of this paper for their valuable comments and insights. Their contributions have greatly improved the quality of this study.

\section{References}

Anderson, C. E., McDougald, J. S., \& Cuesta Medina, L. (2015). CLIL for young learners. In C. N. Giannikas, L. McLaughlin, G. Fanning, \& N. Deutsch Muller (Eds.), Children learning English: From research to practice (pp. 137-151). Reading: Garnett Education.

Bach, K., \& Harnish, R. M. (1979). Communication and Speech Acts. Cambridge, Mass.: Harvard University Press.

Benelli, B., Belacchi, C., Gini, G., \& Lucangeli, D. (2006). 'To define means to say what you know about things': the development of definitional skills as metalinguistic acquisition. Journal of Child Language, 33(1), 71-97. https://doi.org/10.1017/S0305000905007312

Cenoz, J. (2013). The influence of bilingualism on third language acquisition: Focus on multilingualism. Language Teaching, 46(1), 71-86. https://doi.org/10.1017/S0261444811000218

Cenoz, J., Genesee, F., \& Gorter, D. (2014). Critical analysis of CLIL: Taking stock and looking forward. Applied linguistics, 35(3), 243-262. https://doi.org/10.1093/applin/amt011

Cummins, J. (1979). 'Cognitive/academic language proficiency, linguistic interdependence, the optimum age question and some other matters', Working Papers on Bilingualism, 19, 121-129.

Cummins, J. (2000). Language, power, and pedagogy: Bilingual children in the crossfire (Vol. 23). Clevedon: Multilingual Matters. https://doi.org/10.21832/9781853596773

Dalton-Puffer, C. (2005). Negotiating interpersonal meanings in naturalistic classroom discourse: directives in content-and-language-integrated classrooms. Journal of Pragmatics, 37(8), 1275-1293. https://doi.org/10. 1016/j.pragma.2004.12.002

Dalton-Puffer, C. (2007). Discourse in content and language integrated learning (CLIL) classrooms (Vol. 20). Amsterdam: John Benjamins. https://doi.org/10.1075/11lt.20

Dalton-Puffer, C. (2008). Outcomes and processes in Content and Language Integrated Learning (CLIL): current research from Europe. In W. Delanoy, \& L. Volkmann (Eds.), Future perspectives for English language teaching (pp.139-157). Heidelberg: Universitätsverlag Winter.

Dalton-Puffer, C., \& Nikula, T. (2006). Pragmatics of content-based instruction: Teacher and student directives in Finnish and Austrian classrooms. Applied Linguistics, 27(2), 241-267. https://doi.org/10.1093/appli $\mathrm{n} / \mathrm{am} 1007$

Dalton-Puffer, C., Nikula, T., \& Smit, U. (Eds.). (2010). Language use and language learning in CLIL classrooms (Vol. 7). Amsterdam: John Benjamins. https://doi.org/10.1075/aals.7

De Graaff, R., Jan Koopman, G., Anikina, Y., \& Westhoff, G. (2007). An observation tool for effective L2 pedagogy in content and language integrated learning (CLIL). International Journal of Bilingual Education and Bilingualism, 10(5), 603-624. https://doi.org/10.2167/beb462.0

European Commission. Directorate-General XXII, \& Youth. (1996). Teaching and Learning: towards the learning society (Vol. 42). Office for Official Publications of the European Communities.

Frigols Martín, M. J. (2008). CLIL implementation in Spain: An approach to different models. In C. M. Coonan (Ed.), CLIL e l'apprendimento delle lingue. Le sfide del nuovo ambiente di apprendimento (pp. 221-232). Venezia: Libreria Editrice Cafoscarina.

Garton, S. (2012). Speaking out of turn? Taking the initiative in teacher-fronted classroom interaction. Classroom Discourse, 3(1), 29-45. https://doi.org/10.1080/19463014.2012.666022

Gibbons, P. (1998). Classroom talk and the learning of new registers in a second language. Language and Education, 12(2), 99-118. https://doi.org/10.1080/09500789808666742

Halliday, M. A. K. (1994). An introduction to functional grammar (2nd ed.). London: Edward Arnold.

Hamers, J. F., \& Blanc, M. (1989). Bilinguality and Bilingualism. Cambridge: Cambridge University Press. 
Henrichs, L. F. (2010). Academic language in early childhood interactions: a longitudinal study of 3- to 6-year-old Dutch monolingual children. (Doctoral dissertation) University of Amsterdam, Boxpress.nl

Henrichs, L. F., \& Leseman, P. P. (2014). Early science instruction and academic language development can go hand in hand. The promising effects of a low-intensity teacher-focused intervention. International Journal of Science Education, 36(17), 2978-2995. https://doi.org/10.1080/09500693.2014.948944

Hoff, E. (2006). How social contexts support and shape language development. Developmental Review, 26(1), 55-88. https://doi.org/10.1016/j.dr.2005.11.002

Jessner, U. (2008). A DST model of multilingualism and the role of metalinguistic awareness. The Modern Language Journal, 92(2), 270-283. https://doi.org/10.1111/j.1540-4781.2008.00718.x

Jiménez Catalán, R. M., \& Ruiz de Zarobe, Y. (2007). Does the type of instruction have any bearing on EFL learners' receptive vocabulary. Conference paper presented at ELIA X, 14-16, March, University of Seville.

Jiménez Catalán, R. M., \& Ruiz de Zarobe, Y. (2009). The receptive vocabulary of EFL learners in two instructional contexts: CLIL versus non-CLIL instruction. In Y. Ruiz de Zarobe, \& R. M. Jiménez Catalán (Eds.), Content and language integrated learning: Evidence from research in Europe (pp. 81-92). Clevedon: Multilingual Matters. https://doi.org/10.21832/9781847691675-008

Jiménez Catalán, R. M., Ruiz de Zarobe, Y., \& Cenoz, J. (2006). Vocabulary profiles of English foreign language learners in English as a subject and as a vehicular language. VIEWZ: Vienna English Working Papers, 15(3), 23-27.

Kloth, S., Janssen, P., Kraaimaat, F., \& Brutten, G. J. (1998). Communicative styles of mothers interacting with their preschool-age children: A factor analytic study. Journal of Child Language, 25(1), 149-168. https://doi.org/10.1017/S0305000997003334

Llinares, A. (2015). Integration in CLIL: A proposal to inform research and successful pedagogy. Language, Culture and Curriculum, 28(1), 58-73. https://doi.org/10.1080/07908318.2014.1000925

Llinares, A., Morton, T., \& Whittaker, R. (2012). The roles of language in CLIL. Stuttgart: Ernst Klett Sprachen.

Lorenzo, F. (2007). An analytical framework of language integration in L2 content-based courses: The European dimension. Language and Education, 21(6), 502-514. https://doi.org/10.2167/le708.0

Lorenzo, F. (2017). Historical literacy in bilingual settings: Cognitive academic language in CLIL history narratives. Linguistics and Education, 37, 32-41. https://doi.org/10.1016/j.linged.2016.11.002

Lorenzo, F., \& Rodríguez, L. (2014). Onset and expansion of L2 cognitive academic language proficiency in bilingual settings: CALP in CLIL. System, 47, 64-72. https://doi.org/10.1016/j.system.2014.09.016

Marsh, D. (2008). Language awareness and CLIL. In S. May, \& N. H. Hornberger (Eds.), Encyclopedia of language and education (pp. 1986-1999). Boston: Springer. https://doi.org/10.1007/978-0-387-3042 4-3-152

Nashaat Sobhy, N. (2017). Investigating pragmatics in CLIL through students' requests. In A. Llinares, \& T. Morton (Eds.), Applied Linguistics Perspectives on CLIL (pp.67-88). Amsterdam: John Benjamins. https://doi.org/10.1075/11lt.47.05sob

Nikula, T. (2002). Teacher talk reflecting pragmatic awareness. Pragmatics. Quarterly Publication of the International Pragmatics Association (IPrA), 12(4), 447-467. https://doi.org/10.1075/prag.12.4.03nik

Nikula, T. (2008). Learning pragmatics in content-based classrooms. In E. Alcón, \& A. Martínez-Flor (Eds.), Investigating Pragmatics in Foreign Language Learning, Teaching and Testing. Clevedon: Multilingual Matters. https://doi.org/10.21832/9781847690869-007

Nikula, T. (2007). The IRF pattern and space for interaction: comparing CLIL and EFL classrooms. In C. Dalton-Puffer (Ed.), Empirical Perspectives on CLIL Classroom Discourse (pp. 179-204). Frankfurt: Peter Lang.

Nippold, M. A., Hegel, S. L., Sohlberg, M. M., \& Schwarz, I. E. (1999). Defining abstract entities: Development in pre-adolescents, adolescents, and young adults. Journal of Speech, Language, and Hearing Research, 42(2), 473-481. https://doi.org/10.1044/jslhr.4202.473

Pascual Peña, I. (2010). Teachers' questions in CLIL contexts. VIEWZ: Vienna English Working Papers, 19(3), 65-71.

Pinilla-Padilla, C. (2006). Multilingualism in the educational system in Valencia, Spain. In M. L. McCloskey, J. 
Orr, \& M. Dolitsky (Eds.), Teaching English as a Foreign Language in Primary School. Case Studies in TESOL Practice Series (pp. 9-24). Alexandria: Teachers of English to Speakers of Other Languages, Inc.

Portolés, L., (2015). Multilingualism and Very Young Learners: An Analysis of Pragmatic Awareness and Language Attitudes. Boston: de Gruyter (Series Trends in Applied Linguistics 12). https://doi.org/10.151 $5 / 9781501500022$

Portolés, L. \& Safont, P. (2018). Examining authentic and elicited data from a multilingual perspective. The real picture of child requestive behaviour in the L3 classroom. System, 75, 81-92. https://doi.org/10.1016/j. system.2018.03.012

Ruiz de Zarobe, Y. (2008). CLIL and foreign language learning: A longitudinal study in the Basque Country. International CLIL Research Journal, 1(1), 60-73.

Ruiz de Zarobe, Y. (2011). Which language competencies benefit from CLIL? An insight into applied linguistics research. In Y. Ruiz de Zarobe, J. M. Sierra, \& F. G. del Puerto (Eds.), Content and foreign language integrated learning: Contributions to multilingualism in European contexts (pp. 129-153). Frankfurt: Peter Lang. https://doi.org/10.3726/978-3-0351-0171-3

Ruiz de Zarobe, Y., \& Jiménez Catalán, R. M. (Eds.). (2009). Content and language integrated learning: Evidence from research in Europe (Vol. 41). Clevedon: Multilingual Matters. https://doi.org/10.218 32/9781847691675

Safont, P. (2018). Are Classroom Requests Similar in All EFL Settings? Focusing on a Young Multilingual Learning Environment. In P. Romanowski \& M. Jedynak, Current Research in Bilingualism and Bilingual Education (pp. 123-141). Berlin: Springer. https://doi.org/10.1007/978-3-319-92396-3_7

Safont, P., \& Portolés, L. (2015). Pragmatic awareness in early consecutive third language learners. In P. Safont, \& L. Portolés (Eds.), Learning and using multiple languages: Current findings from research on multilingualism (pp. 218-237). Newcastle: Cambridge Scholars Publishing.

Safont, P., \& Portolés, L. (2016). Pragmatic functions of formulaic speech in three different languages. A focus on early L3 learners of English. Journal of Immersion and Content-Based Language Education, 4(2), 225-250. https://doi.org/10.1075/jicb.4.2.04saf

Scarcella, R. (2003). Academic English: A Conceptual Framework. Technical Report 2003-1. University of California Linguistic Minority Research Institute.

Searle, J. R. (1979). Expression and meaning: Studies in the theories of speech acts. Cambridge: Cambridge University Press. https://doi.org/10.1017/CBO9780511609213

Snow, C. E. (2010). Academic language and the challenge of reading for learning about science. Science, 328(5977), 450-452. https://doi.org/10.1126/science.1182597

Snow, C. E. (2014). Input to interaction to instruction: three key shifts in the history of child language research. Journal of Child Language, 41(S1), 117-123. https://doi.org/10.1017/S0305000914000294

Snow, C. E., \& Uccelli, P. (2009). The challenge of academic language. In D. R. Olson, \& N. Torrance, (Eds.), The Cambridge handbook of literacy (pp. 112-133). Cambridge: Cambridge University Press. https://doi.org/10.1017/CBO9780511609664.008

Snow, C. E., Tabors, P. O., Nicholson, P. A., \& Kurland, B. F. (1995). SHELL: Oral language and early literacy skills in kindergarten and first-grade children. Journal of Research in Childhood education, 10(1), 37-48. https://doi.org/10.1080/02568549509594686

Snow, M. A., Met, M., \& Genesee, F. (1989). A conceptual framework for the integration of language and content in second/foreign language instruction. TESOL Quarterly, 23(2), 201-217. https://doi.org/10.23 $07 / 3587333$

Uccelli, P., Barr, C. D., Dobbs, C. L., Galloway, E. P., Meneses, A., \& Sanchez, E. (2015). Core academic language skills: An expanded operational construct and a novel instrument to chart school-relevant language proficiency in preadolescent and adolescent learners. Applied Psycholinguistics, 36(5), 1077-1109. https://doi.org/10.1017/S014271641400006X

Van Lier, L. (1996). Interaction in the language classroom: Awareness, autonomy and authenticity. London: Longman.

Walsh, S. (2002). Construction or obstruction: Teacher talk and learner involvement in the EFL classroom. 
Language Teaching Research, 6(1), 3-23. https://doi.org/10.1191/13621688021r095oa

\section{Copyrights}

Copyright for this article is retained by the author(s), with first publication rights granted to the journal.

This is an open-access article distributed under the terms and conditions of the Creative Commons Attribution license (http://creativecommons.org/licenses/by/4.0/). 